\title{
Eco-innovations for a circular economy: the EU countries rankings
}

\author{
Konstantin G. Gomonov* \\ Peoples' Friendship University of Russia (RUDN University), 6 Miklukho-Maklaya Street, 117198 \\ Moscow, Russian Federation
}

\begin{abstract}
This article reveals the importance of implementing ecoinnovation for the circular economy and sustainable development. The author provides different approaches to measuring the level of development of eco-innovation in the countries of the European Union. The two main indices for measuring eco-innovation are revealed in more detail. Described the pillars of each of the indices. Clustering of EU countries was carried out using the k-means method and groups of countries were identified by the level of implementation of eco-innovation. The clear leaders are Denmark, Sweden. Bulgaria, Cyprus, Poland are catching-up countries.
\end{abstract}

\section{Introduction}

Currently, in most developed countries, the government direction of development is associated with the formation of a "green" economy and the concept of sustainable development. This concept is based on a harmonious combination of environmental, economic and social factors. At the same time, the priorities of society's development are built from environmental restrictions through a fair distribution of public resources - to the efficiency of economic development. Thus, almost the entire world community is currently confronted with the challenge associated with the threat of environmental safety. The renewal of natural resources is hindered by a significant increase in production and consumption of products. This leads to tangible signs of an environmental crisis, such as environmental pollution, climate change and an increase in the frequency of natural and man-made disasters [1].

Eco-innovations are necessary factor in preventing a global environmental disaster. The disruption of the natural balance and the deterioration of the interaction between society and the environment are a consequence of the development of the technogenic economy in the world. The key direction in solving the problems described above is the use of the concept of "green growth", which contributes to sustainable economic development and allows funds to be redirected to meet the needs of society. The concept of sustainable development combines three main aspects: economic, social and environmental [2]. In a market economy, sustainable development is achieved by increasing the efficiency of

\footnotetext{
*Corresponding author: gomonov-kg@rudn.ru
} 
resource use through the introduction of more advanced and environmentally friendly technologies, recycling production waste and their further consumption.

Eco-innovations are considered a key element in making the transition from a linear economy to a circular system of production and consumption. The transition to a circular economy depends on systematic eco-innovation, which includes not only technology intensive but also dynamic and holistic combinations of innovative services and new efficient organizational structures and management systems.

The concept of eco-innovation has emerged as an approach that contributes to the sustainable development of all societies around the world. Eco-innovation can be defined as "all efforts from relevant actors that introduce, develop, and apply new ideas, behaviors, products and processes and contribute to reducing environmental burdens or ecologically specified sustainability targets" [3]. Eco-innovation plays a key role in promoting and implementing green growth because it promotes all forms of innovation that reduce environmental impacts and strengthen resilience to environmental pressures [4].

\section{Materials and methods}

There are various approaches to measuring eco-innovation, for example, eco-innovation can be measured directly or indirectly [5]. Another approach [6] proposes to classify measures into four types for quantifying technological change considering the ecoinnovation process: input measures, output measures, direct outcome measures and indirect impact measures. A review of the various approaches shows that in order to create a measurable index, it is important to understand the details of eco-innovation concepts. Based on the research done to date, the types of innovation that need to be considered when measuring eco-innovation are as follows: Product Innovation, Process Innovation, Marketing Innovation, Organizational Innovation, Material Flow Innovation, and Social Innovation [7,8]. According to the OECD methodology, eco-innovation considers only product innovation, technological innovation, marketing innovation and organizational innovation as the main types of eco-innovation. The EIO approach [8] highlighted the importance of innovation in material flows and social innovation. As the scope expanded, eco-innovation began to embrace different environments around companies and interactions between stakeholders. This means that material flows are also considered together with economic activities, both in their physical and socio-economic dimensions.

The purpose of the study is to consider two approaches to measuring eco-innovation in the European Union, on the basis of statistical data, to determine the leading countries in the development of this direction, that is, to carry out the clustering of countries.

In order to evaluate the eco-innovation performance across all EU Member States, a composite index has been developed by the Eco-Innovation Observatory. [9]. The EcoInnovation Index (Eco-IS) shows the effectiveness of eco-innovation in the EU member states. The index covers various areas of eco-innovation by contributing 16 indicators grouped into five areas: eco-innovation inputs, eco-innovation activities, eco-innovation outputs, resource efficiency and socio-economic outcomes. The Eco-Innovation Index measures how well individual member states perform in various aspects of eco-innovation. The Eco-Innovation Index complements other approaches to measuring innovation in EU countries and aims to promote a holistic view of economic, environmental and social performance. Table 1 illustrates the relationship between the components of the EcoInnovation Index and the sustainable development goals. 
Table 1. The Eco-Innovation Index and the sustainable development goals [10].

\begin{tabular}{|c|c|c|}
\hline Component & Indicator & SDGs \\
\hline \multirow{3}{*}{$\begin{array}{l}\text { ECO- } \\
\text { INNOVATION } \\
\text { INPUTS }\end{array}$} & $\begin{array}{l}\text { Governments environmental and energy } \\
\text { R\&D appropriations and outlays ( } \% \text { of } \\
\text { GDP) }\end{array}$ & $\begin{array}{l}\text { Goal } 8 \text { - Decent work and } \\
\text { economic growth } \\
\text { Goal } 9 \text { - Industry, innovation and } \\
\text { infrastructure }\end{array}$ \\
\hline & $\begin{array}{l}\text { Total R\&D personnel and researchers } \\
\text { (\% of total employment) }\end{array}$ & $\begin{array}{l}\text { Goal } 8 \text { - Decent work and } \\
\text { economic growth }\end{array}$ \\
\hline & $\begin{array}{l}\text { Total value of green early stage } \\
\text { investments (USD/capita) }\end{array}$ & $\begin{array}{l}\text { Goal } 9 \text { - Industry, innovation and } \\
\text { infrastructure }\end{array}$ \\
\hline \multirow{3}{*}{$\begin{array}{l}\text { ECO- } \\
\text { INNOVATION } \\
\text { ACTIVITIES }\end{array}$} & $\begin{array}{l}\text { Implementation of resource efficiency } \\
\text { actions among SMEs (Score) }\end{array}$ & $\begin{array}{l}\text { Goal } 9 \text { - Industry, innovation and } \\
\text { infrastructure } \\
\text { Goal } 12 \text { - Responsible } \\
\text { consumption and production }\end{array}$ \\
\hline & $\begin{array}{l}\text { Implementation of sustainable products } \\
\text { among SMEs ( } \% \text { of surveyed firms) }\end{array}$ & $\begin{array}{l}\text { Goal } 7 \text { - Affordable and clean } \\
\text { energy } \\
\text { Goal } 9 \text { - Industry, innovation and } \\
\text { infrastructure } \\
\text { Goal } 12 \text { - Responsible } \\
\text { consumption and production }\end{array}$ \\
\hline & $\begin{array}{l}\text { Number of ISO } 14001 \text { certificates (per } \\
\text { mln population) }\end{array}$ & $\begin{array}{l}\text { Goal } 9 \text { - Industry, innovation and } \\
\text { infrastructure } \\
\text { Goal } 12 \text { - Responsible } \\
\text { consumption and production }\end{array}$ \\
\hline \multirow{3}{*}{$\begin{array}{l}\text { ECO- } \\
\text { INNOVATION } \\
\text { OUTPUTS }\end{array}$} & $\begin{array}{l}\text { - Eco-innovation related patents (per } \\
\text { mln population) }\end{array}$ & $\begin{array}{l}\text { Goal } 9 \text { - Industry, innovation and } \\
\text { infrastructure } \\
\text { Goal } 12 \text { - Responsible } \\
\text { consumption and production }\end{array}$ \\
\hline & $\begin{array}{l}\text { - Eco-innovation related academic } \\
\text { publications (per mln population) }\end{array}$ & $\begin{array}{l}\text { Goal } 9 \text { - Industry, innovation and } \\
\text { infrastructure }\end{array}$ \\
\hline & $\begin{array}{l}\text { - Eco-innovation related media } \\
\text { coverage (per mln population) }\end{array}$ & $\begin{array}{l}\text { Goal } 9 \text { - Industry, innovation and } \\
\text { infrastructure }\end{array}$ \\
\hline \multirow{3}{*}{$\begin{array}{l}\text { ECO- } \\
\text { INNOVATION } \\
\text { SOCIO- } \\
\text { ECONOMIC } \\
\text { OUTCOMES }\end{array}$} & $\begin{array}{l}\text { - Exports of products from eco- } \\
\text { industries (\% of total exports) }\end{array}$ & $\begin{array}{l}\text { Goal } 9 \text { - Industry, innovation and } \\
\text { infrastructure }\end{array}$ \\
\hline & $\begin{array}{l}\text { - Employment in environmental } \\
\text { protection and resource management } \\
\text { activities ( } \% \text { of workforce) }\end{array}$ & $\begin{array}{l}\text { Goal } 8 \text { - Decent work and } \\
\text { economic growth } \\
\text { Goal } 9 \text { - Industry, innovation and } \\
\text { infrastructure }\end{array}$ \\
\hline & $\begin{array}{l}\text { - Value added in environmental } \\
\text { protection and resource management } \\
\text { activities (\% of GDP) }\end{array}$ & $\begin{array}{l}\text { Goal } 9 \text { - Industry, innovation and } \\
\text { infrastructure }\end{array}$ \\
\hline \multirow{4}{*}{$\begin{array}{l}\text { ECO- } \\
\text { INNOVATION } \\
\text { RESOURCE } \\
\text { EFFICIENCY } \\
\text { OUTCOMES }\end{array}$} & $\begin{array}{l}\text { - Material productivity (GDP/Domestic } \\
\text { Material Consumption) }\end{array}$ & $\begin{array}{l}\text { Goal } 9 \text { - Industry, innovation and } \\
\text { infrastructure } \\
\text { Goal } 12 \text { - Responsible } \\
\text { consumption and production }\end{array}$ \\
\hline & $\begin{array}{l}\text { - Water productivity (GDP/total fresh } \\
\text { water abstraction) }\end{array}$ & $\begin{array}{l}\text { Goal } 6 \text { - Clean water and } \\
\text { sanitation }\end{array}$ \\
\hline & $\begin{array}{l}\text { - Energy productivity (GDP/gross } \\
\text { inland energy consumption) }\end{array}$ & $\begin{array}{l}\text { Goal } 7 \text { - Affordable and clean } \\
\text { energy } \\
\text { Goal } 9 \text { - Industry, innovation and } \\
\text { infrastructure }\end{array}$ \\
\hline & $\begin{array}{l}\text { - GHG emissions intensity } \\
(\mathrm{CO} 2 \mathrm{e} / \mathrm{GDP})\end{array}$ & Goal 13 - Climate action \\
\hline
\end{tabular}


Eco-innovation inputs comprise investments (financial or human resources) aiming to trigger eco-innovation activities. Eco-innovation activities includes indicators to monitor the scope and scale of eco-innovation activities undertaken by companies. The component focuses on efforts and activities rather than on actual results of innovation activity. Ecoinnovation outputs describe the immediate results of eco-innovation activities. Indicators in this component are used to monitor the extent to which knowledge outputs generated by businesses and researchers relate to eco-innovation. Socio-economic outcomes of ecoinnovation depict wider effects of eco-innovation activities for society and the economy. This includes changes in employment, turnover or exports that can be related to broadly understood eco-innovation activities. Resource efficiency outcomes relate to wider effects of eco-innovation on improved resource productivity. Eco-innovation can have a twofold positive impact on resource efficiency: it can increase the generated economic value, while at the same time decrease pressures on the natural environment.

The second significant index for assessing eco-innovation - ASEI. It attempts to measure actual eco-innovation both quantitatively and qualitatively using data sources compiled and calculated from various international organizations. This index consists of the following main pillars 1) Eco-Innovation Capacity, 2) Eco-Innovation Supporting Environment, 3) Eco-Innovation Activity and 4) Eco-Innovation Performance. EcoInnovation Capacity measures competitive potential of nation's eco-innovation level in terms of both social, economic and human resources. Eco-Innovation Supporting Environment measures nation's political and financial support on eco-innovation based on government spending, political priorities and etc. Eco-Innovation Activity reflects actual level of actions taken by government, academy and companies with respect to enhancing level of nation's eco-innovational growth. Eco-Innovation performance demonstrates what nation has accomplished in order to tackle environmental, economic and social standpoint of eco-innovation [11]. Table 2 shows the relationship between the ASEI and the Sustainable Development Goals.

Table 2. The ASEI and the sustainable development goals [11].

\begin{tabular}{|c|c|c|}
\hline Component & Indicator & SDGs \\
\hline \multirow{5}{*}{$\begin{array}{l}\text { ECO-INNOVATION } \\
\text { CAPACITY }\end{array}$} & $\begin{array}{l}\text { 1.1. Nation's Economic } \\
\text { Competitiveness }\end{array}$ & $\begin{array}{l}\text { Goal } 8 \text { - Decent work and economic } \\
\text { growth } \\
\text { Goal } 12 \text { - Responsible consumption } \\
\text { and production }\end{array}$ \\
\hline & $\begin{array}{l}\text { 1.2. Nation's General Innovation } \\
\text { Capacity }\end{array}$ & $\begin{array}{l}\text { Goal } 8 \text { - Decent work and economic } \\
\text { growth } \\
\text { Goal } 12 \text { - Responsible consumption } \\
\text { and production }\end{array}$ \\
\hline & $\begin{array}{l}\text { 1.3. Green Technology R\&D } \\
\text { Institution Capacity }\end{array}$ & $\begin{array}{l}\text { Goal } 9 \text { - Industry, innovation and } \\
\text { infrastructure }\end{array}$ \\
\hline & $\begin{array}{l}\text { 1.4. Green Technology } \\
\text { possessed/acquired Enterprises }\end{array}$ & $\begin{array}{l}\text { Goal } 9 \text { - Industry, innovation and } \\
\text { infrastructure }\end{array}$ \\
\hline & $\begin{array}{l}\text { 1.5. Awareness of Sustainability } \\
\text { Management }\end{array}$ & $\begin{array}{l}\text { Goal } 12 \text { - Responsible consumption } \\
\text { and production }\end{array}$ \\
\hline \multirow{4}{*}{$\begin{array}{l}\text { ECO-INNOVATION } \\
\text { SUPPORTING } \\
\text { ENVIRONMENT }\end{array}$} & $\begin{array}{l}\text { 2.1. Government's R\&D expenditure } \\
\text { in Green Industry }\end{array}$ & $\begin{array}{l}\text { Goal } 9 \text { - Industry, innovation and } \\
\text { infrastructure } \\
\text { Goal } 12 \text { - Responsible consumption } \\
\text { and production }\end{array}$ \\
\hline & $\begin{array}{l}\text { 2.2. Implementation of } \\
\text { Environmental Regulations }\end{array}$ & $\begin{array}{l}\text { Goal } 16 \text { - Peace, justice and strong } \\
\text { institutions }\end{array}$ \\
\hline & $\begin{array}{l}\text { 2.3. Maturity of Investment Setting } \\
\text { for Green Technology Industry }\end{array}$ & $\begin{array}{l}\text { Goal } 9 \text { - Industry, innovation and } \\
\text { infrastructure }\end{array}$ \\
\hline & $\begin{array}{l}\text { 2.4. Investment Scale of Green } \\
\text { Technology SMEs }\end{array}$ & $\begin{array}{l}\text { Goal } 9 \text { - Industry, innovation and } \\
\text { infrastructure }\end{array}$ \\
\hline
\end{tabular}


Table 2. Continued

\begin{tabular}{|c|c|c|}
\hline \multirow{5}{*}{$\begin{array}{l}\text { ECO-INNOVATION } \\
\text { ACTIVITIES }\end{array}$} & $\begin{array}{l}\text { 3.1. Commercialization Level of } \\
\text { Green Technology }\end{array}$ & $\begin{array}{l}\text { Goal } 12 \text { - Responsible consumption } \\
\text { and production }\end{array}$ \\
\hline & $\begin{array}{l}\text { 3.2. Enterprises' Participation on } \\
\text { Environmental Management System }\end{array}$ & $\begin{array}{l}\text { Goal } 12 \text { - Responsible consumption } \\
\text { and production }\end{array}$ \\
\hline & $\begin{array}{l}\text { 3.3. Economic Influence of Leading } \\
\text { Environmentally Responsive } \\
\text { Enterprises }\end{array}$ & $\begin{array}{l}\text { Goal } 9 \text { - Industry, innovation and } \\
\text { infrastructure }\end{array}$ \\
\hline & 3.4. Green Patents & $\begin{array}{l}\text { Goal } 12 \text { - Responsible consumption } \\
\text { and production }\end{array}$ \\
\hline & $\begin{array}{l}\text { 3.5. Activeness of Renewable Energy } \\
\text { Utilization }\end{array}$ & Goal 7 - Affordable and clean energy \\
\hline \multirow{6}{*}{$\begin{array}{l}\text { ECO-INNOVATION } \\
\text { PERFORMANCES }\end{array}$} & $\begin{array}{l}\text { 4.1. Level of Environmental Impact } \\
\text { on Society }\end{array}$ & $\begin{array}{l}\text { Goal } 3 \text { - Good health and well-being } \\
\text { Goal } 12 \text { - Responsible consumption } \\
\text { and production }\end{array}$ \\
\hline & 4.2. $\mathrm{CO} 2$ Emission Intensity & Goal 13 - Climate action \\
\hline & $\begin{array}{l}\text { 4.3. Nation's Energy sustainability } \\
\text { level }\end{array}$ & Goal 7 - Affordable and clean energy \\
\hline & 4.4. Water Consumption Intensity & Goal 6 - Clean water and sanitation \\
\hline & $\begin{array}{l}\text { 4.5. Jobs in Green Technology } \\
\text { Industry }\end{array}$ & $\begin{array}{l}\text { Goal } 8 \text { - Decent work and economic } \\
\text { growth } \\
\text { Goal } 9 \text { - Industry, innovation and } \\
\text { infrastructure }\end{array}$ \\
\hline & 4.6. Green Industry Market Size & $\begin{array}{l}\text { Goal } 8 \text { - Decent work and economic } \\
\text { growth } \\
\text { Goal } 9 \text { - Industry, innovation and } \\
\text { infrastructure }\end{array}$ \\
\hline
\end{tabular}

The k-means method was chosen as the method of clustering. Data processing was carried out in the object-oriented Python environment. KMeans algorithm clusters data by trying to separate samples in $\mathrm{n}$ groups of equal variances, minimizing a criterion known as the inertia or within-cluster sum-of-squares. This algorithm requires the number of clusters to be specified. It scales well to a large number of samples and has been used across a large range of application areas in many different fields.

The k-means algorithm divides a set of $\mathrm{N}$ samples $\mathrm{X}$ into $\mathrm{K}$ disjoint clusters $\mathrm{C}$, each described by the mean $\mu \mathrm{j}$ of the samples in the cluster. The means are commonly called the cluster "centroids"; note that they are not, in general, points from X, although they live in the same space. The K-means algorithm aims to choose centroids that minimize the inertia, or within-cluster sum-of-squares criterion [12]:

$$
\sum_{i=0}^{n} \min _{\mu_{j} \in C}\left(\left\|x_{i}-\mu_{j}\right\|^{2}\right)
$$

Inertia can be recognized as a measure of how internally coherent clusters are [12].

\section{Results}

The analyzed period is explained by the presence of calculated indices: for Eco-IS index is 2010-2019 and for ASEI index 2015-2017. We used the Elbow method to determine the optimal number of clusters in both indices. The basic idea behind partitioning methods, such as k-means clustering, is to define clusters such that the total intra-cluster variation [or total within-cluster sum of square (WSS)] is minimized. The complete WSS measures the 
compactness of the clustering and we want it to be as small as possible [13]. The optimal number of clusters in both cases is four clusters. The results of the Elbow method are shown in Figure 1.
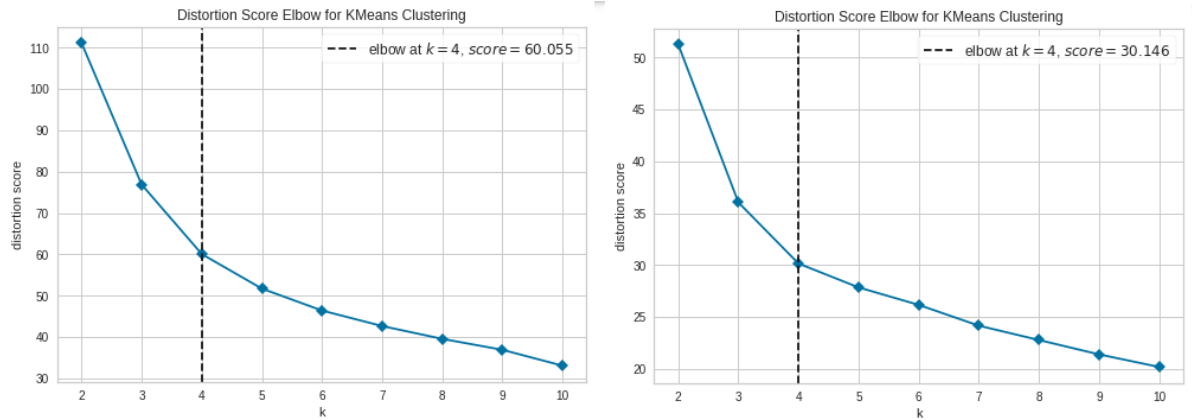

Fig. 1. The optimal number of clusters according to the Elbow method. (left) Eco-IS index; (right) ASEI index.

Source: Compiled by the authors

Silhouette analysis shows the distance between the resulting clusters. The silhouette plot (Figure 2) displays a measure of how close each point in one cluster is to points in neighboring clusters. Thus, it allows for a visual assessment of parameters such as the number of clusters.
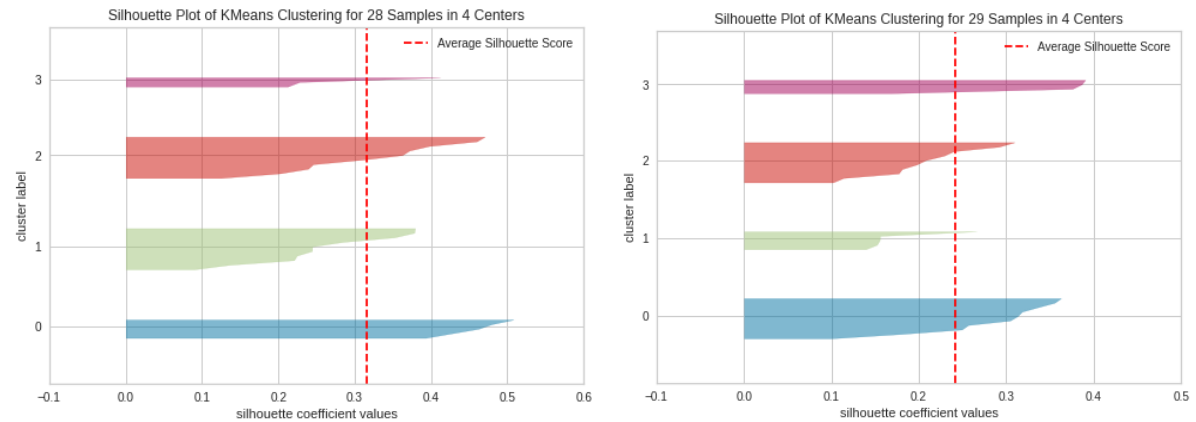

Fig. 2. Silhouette analysis. (left) Eco-IS index; (right) ASEI index.

Source: Compiled by the authors

We see that in the case of Eco-IS index clusters 1 and 2 are more uniform. And in the case of ASEI index clusters 0 and 2 are more uniform. Note that the distribution by clusters primarily considers the dynamics of cluster changes in the period under consideration. The distribution of countries within each cluster for each of the indices is shown in Figure 3. 

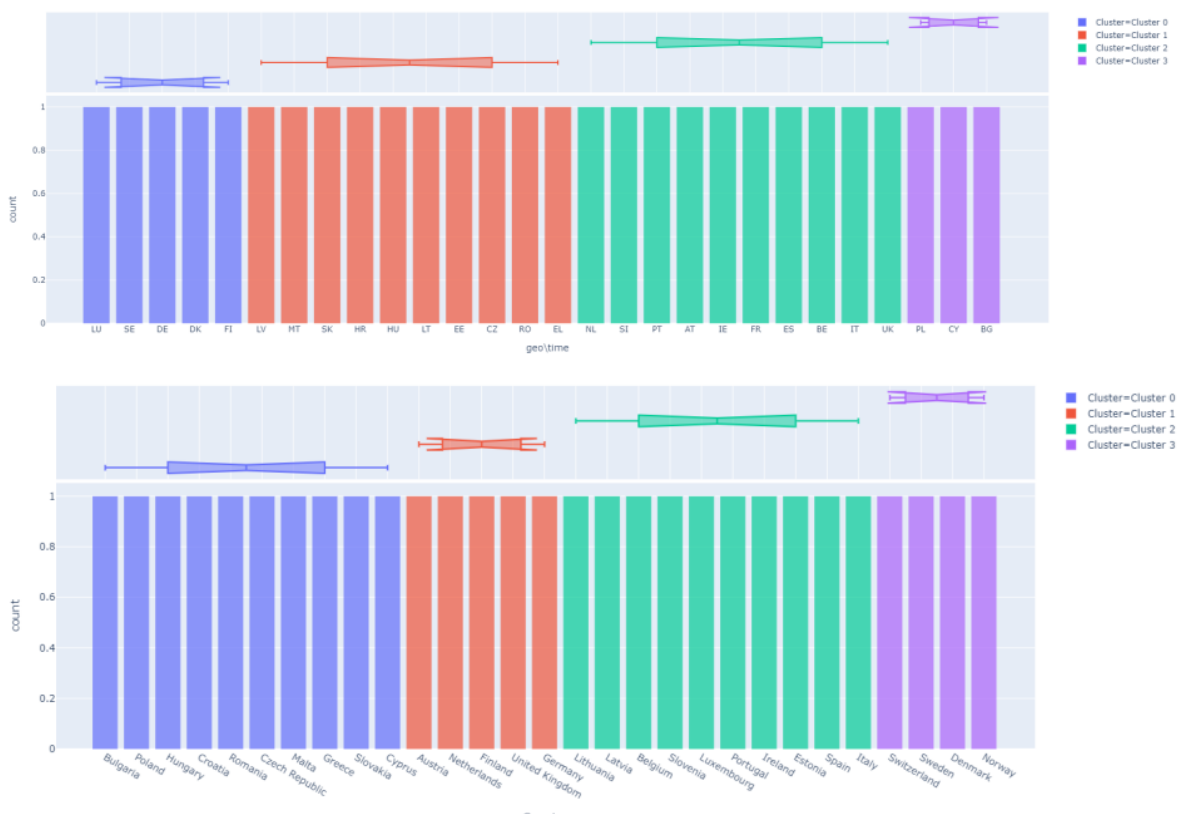

Fig. 3. Distribution of countries within each cluster. (top) Eco-IS index; (bottom) ASEI index. Source: Compiled by the authors

Conducting a comparative analysis of the clustering of the European Union countries by two indices, one can notice that the leaders in this direction have been identified. The characteristics of each cluster are presented in Table 3. The clear leaders in promoting ecoinnovation policy are Denmark, Sweden. These countries are among the leaders in two indices. Bulgaria, Cyprus, Poland are catching-up countries and are included in the corresponding clusters of two indices. The rest of the countries have values around the average. However, it is worth noting that a number of countries: the Netherlands, Germany, Finland, Great Britain are also pursuing an active policy of introducing eco-innovations, which is confirmed by their high values of the indices.

Table 3. Clustering results

\begin{tabular}{|c|c|c|c|c|c|c|}
\hline Index & Cluster & Min & Max & Mean & Country & Type \\
\hline \multirow{4}{*}{$\begin{array}{l}\text { Eco- } \\
\text { IS }\end{array}$} & Cluster 0 & 110 & 165 & 132,68 & $\begin{array}{l}\text { Germany, Denmark, Finland, Luxemburg, } \\
\text { Sweden }\end{array}$ & Liders \\
\hline & Cluster 1 & 42 & 100 & 67,91 & $\begin{array}{c}\text { Czech Republic, Estonia, Greece, Croatia, } \\
\text { Hungary, Lithuania, Latvia, Malta, } \\
\text { Romania, Slovakia }\end{array}$ & Average \\
\hline & Cluster 2 & 71 & 134 & 103,43 & $\begin{array}{l}\text { Austria, Belgium, Spain, France, Ireland, } \\
\text { Italy, Netherlands, Portugal, Slovenia, UK }\end{array}$ & Developers \\
\hline & Cluster 3 & 20 & 66 & 45,13 & Bulgaria, Cyprus, Poland & Catching-up \\
\hline \multirow{4}{*}{ ASEI } & Cluster 0 & 0,23 & 0,37 & 0,30 & $\begin{array}{c}\text { Czech Republic, Malta, Greece, Slovakia, } \\
\text { Cyprus, Croatia, Hungary, Poland, } \\
\text { Romania, Bulgaria }\end{array}$ & Catching-up \\
\hline & Cluster 1 & 0,46 & 0,56 & 0,51 & $\begin{array}{c}\text { Germany, Great Britain, Finland, } \\
\text { Netherlands, Austria }\end{array}$ & Developers \\
\hline & Cluster 2 & 0,35 & 0,45 & 0,40 & $\begin{array}{l}\text { Spain, Estonia, Ireland, Portugal, } \\
\text { Luxemburg, Belgium, Slovenia, Italy, } \\
\text { Latvia, Lithuania }\end{array}$ & Average \\
\hline & Cluster 3 & 0,57 & 0,66 & 0,62 & Norway, Denmark, Sweden, Switzerland & Liders \\
\hline
\end{tabular}




\section{Conclusions}

The study showed that the k-means algorithm allows to divide all countries of the training sample (EU countries) into several clusters, differing in the level of development of ecoinnovations according to two complex indices. And the object-oriented approach allows you to quickly process an unlimited amount of data, including statistical evaluations and building multiple models. We were able to find that the two indices have approximately the same distribution of countries by number among the clusters. The statistic estimate of the silhouette differs slightly. Leaders and catching-up countries stand out clearly.

The results of the study demonstrate the fundamental applicability of classical statistical approaches to solving the problems of strategic management of the development of a circular economy, in particular, eco-innovations. And its' potential effectiveness from the point of view of visibility and information content of reflecting the development of circular processes.

\section{Acknowledgements}

Funding: The publication has been prepared with the support of the grant of the President of the Russian Federation for young scientists candidates of sciences MK-5006.2021.2.

\section{References}

1. P. Mealy, A. Teytelboym, Research Policy (2020)

2. A. Frigon, D. Doloreux, R. Shearmur. J. Clean. Prod., 275 (2020)

3. E. K. Jang, M. S. Park, T. W. Roh, K. J. Han. Sustainability (2015)

4. M. Geissdoerfer, S. N. Morioka, M. M. de Carvalho, S. Evans J. Clean. Prod., 190 (2018)

5. G. Huppes, R. Kleijn, R. Huele, P. Ekins, B. Shaw, M. Esders, S. Schaltegger, Measuring Eco-Innovation: Framework and Typology of Indicators Based on Causal Chains; Final Report of the ECODRIVE Project (CML, University of Leiden: Leiden, The Netherlands, 2008)

6. R. Kemp, P. Pearson, Maastricht, 10 (2007)

7. OECD Oslo Manual: Guidelines for Collecting and Interpreting Innovation Data. Oslo Manual (2005)

8. Eco-Innovation Observatory, Methodological report (2012) https://www.ecoinnovation.eu

9. The Eco-Innovation Scoreboard (Eco-IS) and the Eco-Innovation Index, https://www.eco-innovation.eu

10. M. S. Park, R. Bleischwitz, K. J. Han, E. K. Jang, Sustainability (2017)

11. Comparing Eco-innovation Indices: ASEM Eco-Innovation Index (ASEI) \& EcoInnovation Scoreboard (Eco-IS) (2016) http://www.aseic.org

12. Clustering - scikit-learn 0.22.1 documentation, https://scikit-learn.org

13. Determining The Optimal Number Of Clusters: 3 Must Know Methods, https://www.datanovia.com 